\title{
The Gaps and Flaws in the Current South African Anti-Market Abuse Enforcement Framework in Relation to Selected Aspects of the Financial Markets
}

\author{
Howard Chitimira \\ LLB LLM LLD \\ Lecturer, Faculty of Law, North-West University \\ E-mail: Howard.Chitimira@nwu.ac.za, tafarachitimira@gmail.com
}

\section{Doi:10.5901/mjss.2014.v5n4p236}

Abstract

The objective of this article is to analyse and reveal that the enforcement of market abuse laws has been and still is, problematic in South Africa. In this regard, the article provides an overview analysis of the gaps and flaws in the current antimarket abuse enforcement framework in relation to some selected specific aspects of the financial markets in South Africa. This is primarily done to increase awareness on the part of the general public, policy makers and other relevant stakeholders and to innovate possible solutions to such flaws and challenges in order to enhance the enforcement of the market abuse ban in South Africa. Moreover, this is done to investigate whether the current South African anti-market abuse enforcement framework is robust enough to deal with some market abuse practices that manifested during the recent global financial crisis. In relation to this, the article seeks to explore this and other enforcement-related concerns by, first, taking a closer look at the adequacy of the South African anti-market abuse enforcement framework with regard to market transparency. Secondly, the adequacy of the South African anti-market abuse enforcement framework with regard to investor due diligence will be discussed. Thirdly, the adequacy of the aforementioned enforcement framework will be examined in relation to issuer transparency. Lastly, a similar examination regarding credit rating agencies will be undertaken.

Keywords: market abuse, market transparency, issuer transparency, financial markets, credit rating agencies.

\section{Introduction}

It is generally accepted that there is no comprehensive and satisfactory definition of "market abuse" that exist to date. ${ }^{1}$ However, for the purposes of this article "market abuse" is used as a generic term referring to insider trading and market manipulation. ${ }^{2}$ South Africa had anti-market abuse legislation in place since the late 1990s but nonetheless the enforcement of such legislation to combat market abuse activities has been inconsistent and problematic to date. ${ }^{3}$

\footnotetext{
1 See further Fischel \& Ross "Should the Law Prohibit 'Market Manipulation' in Financial Markets" 1991 Harvard Law Review 503506 \& Avgouleas The Mechanics and Regulation of Market Abuse: A legal and Economic Analysis (2005) 104.

2 These practices are outlawed in South Africa and several other countries globally in a bid to, inter alia, avoid their potential negative effects such as low investor confidence and poor market integrity.

3 Jooste "A critique of the insider trading provisions of the 2004 Securities Services Act" 2006 SALJ 437 441-460; Osode "The new South African Insider Trading Act: Sound law reform or legislative overkill?" 2000 Journal of African Law 239 239; Van Deventer "New watchdog for insider trading" 1999 FSB Bulletin 2 3; the King Task Group into Insider Trading Legislation Minority Report on Insider Trading 1997 para 3.4 as summarised in Beuthin \& Luiz Beuthin's Basic Company Law 3 ed (2000) 235-238; the Van Wyk de Vries Commission of Inquiry into the Companies Act of 1973; Bhana "Take-Over Announcements and Insider Trading Activity on the Johannesburg Stock Exchange" 1987 South African Journal of Business Management 198-208; Botha "Control of Insider Trading in South Africa: A Comparative Analysis" 1991 SA Merc LJ 1-18; Botha "Increased Maximum Fine for Insider Trading: A Realistic and Effective Deterrent?" 1990 SALJ 504-508; also see generally Chitimira The Regulation of Insider Trading in South Africa: A Roadmap for an Effective, Competitive and Adequate Regulatory Statutory Framework (2008) LLM-dissertation, University of Fort Hare, 41-72. See related comments by Van Deventer "Anti-Market Abuse Legislation in South Africa" (10-06-2008) 1-5 <http://www.fsb.co.za/public/ marketabuse/FSBReport.pdf> (accessed 05-05-2013) \& see further Myburgh \& Davis "The Impact of South Africa's Insider Trading Regime: A Report for the Financial Services Board" (25-03-2004) 8-33 <http://www.genesis-analytics.com/public/FSBReport.pdfs (accessed 09-02-2013). Notwithstanding the fact that this Myburgh \& Davis report was published in 2004 before the Securities Services Act 36 of 2004, hereinafter referred to as the Securities Services Act, came into effect and the fact that it was somewhat influenced by the opinions of the interviewees, it shall be referred to in this article where necessary, not as the only basis or evidence of the existence of market abuse activity in the South African financial markets but as a pointer on how market abuse laws were enforced in South Africa prior to the enactment of the Financial Markets Act 19 of 2012, hereinafter referred to as the Financial Markets Act, which came into
} 
Consequently, the objective of this article is to analyse and reveal that the enforcement of market abuse laws has been and still is, problematic in South Africa. ${ }^{4}$ For instance, several factors like the inherent complexities and flaws in the detection, prosecution and prevention of market abuse practices have contributed too many challenges that are associated with the inconsistent enforcement of the market abuse laws in South Africa to date. ${ }^{5}$ In this regard, the article provides an overview analysis of the gaps and flaws in the current anti-market abuse enforcement framework in relation to some selected specific aspects of the financial markets in South Africa. This is primarily done to increase awareness on the part of the general public, policy makers and other relevant stakeholders and to innovate possible solutions to such flaws and challenges in order to enhance the enforcement of the market abuse ban in South Africa. Moreover, this is done to investigate whether the current South African anti-market abuse enforcement framework is robust enough to deal with some market abuse practices that manifested during the recent global financial crisis. Accordingly, the article seeks to explore this and other enforcement-related concerns by, first, taking a closer look at the adequacy of the South African anti-market abuse enforcement framework with regard to market transparency. Secondly, the adequacy of the South African anti-market abuse enforcement framework with regard to investor due diligence will be discussed. Thirdly, the adequacy of the aforementioned enforcement framework will be examined in relation to issuer transparency. Lastly, a similar examination regarding credit rating agencies will be undertaken.

\section{Gaps and Flaws in the Current Anti-Market Abuse Enforcement Framework in Relation to Selected Aspects of the Financial Markets}

The enforcement of the market abuse prohibition in relation to some specific aspects of the South African financial markets as well as selected market abuse challenges that manifested during the recent global financial crisis ${ }^{6}$ will be

effect on 03 June 2013. Notably, the Securities Services Act has now been repealed and will only be referred to where necessary for historical comparative purposes. Moreover, the Myburgh \& Davis report and a few other selected and available sources will be referred to throughout this article because there are currently very few new sources on the enforcement of the market abuse prohibition in South Africa, especially under the Financial Markets Act. Also see Bhattacharya \& Daouk "The World Price of Insider Trading" 2002 Journal of Finance 75 75-108; Lyon \& Du Plessis The Law of Insider Trading in Australia (2005) 159-168 for related comparative analysis in other countries.

4 See further related comments by Van Deventer (10-06-2008) 1-5, available at <http://www.fsb.co.za/public/marketabuse /FSBReport.pdf> (accessed 05-05-2013) \& Myburgh \& Davis (25-03-2004) 8-33, available at <http://www.genesisanalytics.com/public/FSBReport.pdfs (accessed 09-02-2013). Luiz "Prohibition Against Trading on Inside Information-The Saga Continues" 1990 SA Merc LJ 328 328-332; Luiz "Insider Trading Regulation - If at First You Don't Succeed..." 1999 SA Merc LJ 136 136-151; Jooste "Insider Trading: A New Clamp-Down" 1991 BML 248 248-250; Jooste "Insider Dealing in South Africa-The Criminal Aspects" 1990 De Ratione 21 21-28; Henning and Du Toit "The Regulation of False Trading, Market Manipulation and Insider Trading" 2000 Journal for Juridical Science 155 155-165; Osode "The Regulation of Insider Trading in South Africa: A Public Choice Perspective" 1999 African Journal of International and Comparative Law 688 688-708; Van der Lingen "Tougher Legislation to Combat Insider Trading" 1997 FSB Bulletin 10;Van Zyl "Aspekte van Beleggersbeskerming in die Suid-Afrikaanse Reg" 1992 Transactions of the Center for Business Law 231-357; Chanetsa "Insider Trading is Notoriously Hard to Prosecute" Business Report 26 April 2004; Pretorius and Another v Natal South Sea Investment Trust 19653 SA 410 (W), were the courts failed to convict the suspected insider trading offenders. Also see Bhattacharya \& Daouk 2002 Journal of Finance 75-108; Lyon \& Du Plessis The Law of Insider Trading in Australia 159-168 for further related comparative analysis on the enforcement of market abuse laws in other jurisdictions.

5 See the discussion that will ensue later under paragraph 2 below.

${ }^{6}$ The global financial crisis began in the subprime mortgage market of the United States of America (the US) approximately during the period between 2005 and 2006. Notably, increased loan incentives like the provision of relatively easy initial loan terms caused many borrowers to mistakenly believe that they would be able to repay their loans quickly at more favourable terms. Nonetheless, high default rates on subprime and adjustable rate mortgages increased sharply thereafter. Subprime mortgages were a type of loan which gave access to housing to people who did not have the required guarantees to be eligible for ordinary loans and as such, they were high yield mortgages which attracted enormous risks of defaults on the part of the borrowers. The US's subprime mortgages were further classified into securitisation issues, known as mortgage-backed securities which were later sold on the financial markets. In this regard, securitisation refers to a financial operation which enables the sharing of financial risks. Surplus inventory houses and increased interest rates led to a relative drop in the housing prices in the US in 2006 to 2007, and refinancing became a tall order. Defaults and foreclosures soared from around $11 \%$ at the beginning of 2006 to over $20 \%$ in 2008 . About US $\$ 8$ trillion losses were recorded by owners of stock in the US corporations while losses in other countries were averagely estimated at about $23 \%$ and $40 \%$. The US subprime owned houses were now lower than their initial mortgage loan by September 2010. In a nutshell, the 2007 to 2009 global financial crisis was inter alia triggered in part by the inability of the borrowers to repay their subprime mortgages primarily because of their alleged overextending; the resetting of higher interest rates on adjustable rate mortgages; predatory lending and speculation; bad monetary and housing policies; flawed government regulation as well as financial products that distributed and/or concealed the risk of 
highlighted and briefly discussed below to investigate whether the current South African anti-market abuse enforcement framework ${ }^{7}$ is robust enough to deal with such aspects and challenges across all the South African financial markets.

\subsection{Market Transparency}

Transparency is a key element for robust financial markets regulation and good corporate governance in any country. According to the Oxford English Dictionary, the term "transparent" may be literally defined to denote something that is easily seen through, recognised, understood or detected, manifest, evident, obvious and clear. In relation to this, the transparent and timeous publication of all the relevant information is thus an essential ingredient for efficient and free financial markets. ${ }^{8}$ Likewise, for the purposes of this sub-heading, market transparency is defined to include the extent or degree at which the relevant non-public information pertaining to dealing or trading in the financial markets is accurately and timeously published to the financial markets by market participants and the regulatory authorities concerned. ${ }^{9}$ The author concurs with Kaufmann and Weber's contribution that transparency in the financial markets provides legal certainty, establishes some trust among the stakeholders involved, promotes the good values and goals of financial policy and regulation, and enhances accountability of the regulatory authorities. ${ }^{10}$ The 2007 to 2009 global financial crisis exposed some flaws in market transparency regulation. These flaws were prevalent in the secondary financial markets. ${ }^{11}$ Consequently, in the wake of the global financial crisis, market transparency has now become a major priority among several regulators and other enforcement authorities globally. ${ }^{12}$ Given this background, selected aspects of the International Best Practice on market transparency will be briefly highlighted and later contrasted with the South African anti-market abuse enforcement framework below to investigate whether it is comparable to such International Best Practice.

\subsubsection{Overview of the International Best Practice}

Financial markets are regulated by different authorities globally and there is no specific regulatory board that enforces market transparency principles and rules at an international level. ${ }^{13}$ As a result, a number of international non-binding instruments, treaties, codes, best practices and guidelines have been formulated. For instance, the World Trade Organisation (the WTO), the International Monetary Fund (the IMF), the Financial Stability Board, the International Accounting Standards Board (the IASB), the Basel Committee on Banking Supervision (the BCBS) and the International Organisation of Securities Commissions (the IOSCO) have promulgated some rules and guidelines on market transparency and other related aspects of financial markets regulation. ${ }^{14}$

The IOSCO Objectives and Principles of Securities Regulation proposed that there should be post-trade transparency for structured financial products. ${ }^{15}$ Put simply, the IOSCO contends that financial markets regulation should

high mortgage defaults. See Swart The Legal Framework Pertaining to Selected Segments of the Financial Market LLM Dissertation, Nelson Mandela Metropolitan University (2011) 98; Paulo "Europe and the Global Financial Crisis Explained in 10 Sheets: Taking Stock of the EU's Policy Response" April 2011 Fondation Robert Schuman 3 <http://www.robert-schuman.eu/frs-fichecrisefi-qe200-en.pdf> (accessed 04-07-2013); also see related comments by Le Vine \& Malgadi "Mortgage Crises, Derivatives and Economic Chaos" (2009) <http://asbbs.org/files/2009/PDF/M/MalgadiA2.pdf> (accessed 17-07-2013) \& Anonymous "Reason for Global Recession: In Plain Simple English" <http://www.theindianblogger.com/problems/reasons-for-global-recession-in-plain-simple-english> (accessed 07-072013).

7 This refers to the anti-market abuse enforcement framework as provided in the Financial Markets Act.

${ }^{8}$ Kaufmann \& Weber "The Role of Transparency in Financial Regulation" 2010 Journal of International Economic Law 779780.

${ }^{9}$ The IOSCO Objectives and Principles of Securities Regulation May 20036 <http://www.iosco.org/library/pbdocs/pdf/IOSCOPD154.pdf

$>$ (accessed 07-07-2011); Swart The Legal Framework Pertaining to Selected Segments of the Financial Market 117.

10 Kaufmann \& Weber 2010 Journal of International Economic Law 780-786.

11 See generally related comments by the IOSCO Objectives and Principles May 20036 <http://www.iosco.org/library/pbdocs/pdf /IOSCOPD154.pdf > (accessed 07-07-2011); also see similar discussion in the IOSCO Objectives and Principles June 20105 $<$ http://www.iosco.org/library/pbdocs/pdf/IOSCOPD329.pdf > (accessed 07-07-2013).

12 Kaufmann \& Weber 2010 Journal of International Economic Law 780.

13 Kaufmann \& Weber 2010 Journal of International Economic Law 786.

14 Kaufmann \& Weber 2010 Journal of International Economic Law 786.

15 See the IOSCO Task Force on Unregulated Financial Markets and Products Technical Committee Unregulated Financial Markets and Products Final Report September 20099 <http://www.iosco.org/library/pbdocs/pdf/IOSCOPD301.pdf> (accessed 07-07-2013); related remarks by the IOSCO Task Force on Unregulated Financial Markets and Products Consultation Report (05-05-2009) $<$ http://www.iosco.org/library/pbdocs/pdf/IOSCOPD290.pdf> (accessed 07-07-2011). 
endeavour to increase the transparency of trading in such markets. ${ }^{16}$ Moreover, the IOSCO Technical Committee Standing Committee 2 on Regulation of Secondary Markets submits that secondary market reporting systems for different types of structured finance products should be efficient and viable. ${ }^{17}$ Therefore, in order to approve the establishment of new trading systems, the IOSCO considers the reliability of the regulatory authorities' arrangements for monitoring; surveillance; supervision of their participants to promote fairness, efficiency, transparency, confidence and investor protection in the financial markets, as well as the viability of the measures for compliance with the securities laws. ${ }^{18}$ The global financial crisis further revealed that there was a lack of transparency in the over the counter derivative markets. This could have been exacerbated by the fact that over the counter derivatives are not traded on stock exchanges; instead they are negotiated privately between likeminded buyers and sellers. ${ }^{19}$ The author submits that there is still a great need for transparency in over the counter markets as well as in commodity derivatives markets. ${ }^{20}$ For instance, the majority of the credit transactions involving equities, corporate bonds, credit derivatives and cash market instruments are conducted on the over the counter markets where there is little or no centralised sharing of relevant trading information. ${ }^{21}$ This gap led to some difficulties in the detection of market abuse practices involving credit default swaps and credit derivative markets. ${ }^{22}$ In response to this gap, the IOSCO recommended increased transparency in credit default swaps to promote accurate dissemination of information pertaining to prices, trading volumes and trading platforms to assist regulatory authorities to combat market abuse. ${ }^{23}$ Market transparency will promote fairness, competitiveness, efficiency as well as investor confidence in the financial markets. Accordingly, the IOSCO further proposed the establishment of adequate secondary market trading reporting systems to give the relevant stakeholders more accurate information regarding the frequency with which certain securities trades plus the latest information on those trades. These reporting systems are required to be applicable to both the secondary markets and over the counter transactions. ${ }^{24}$

On the other hand, the BCBS ${ }^{25}$ revised its Basel II Accord framework to provide, among other things, market transparency guidelines on banking regulation by adopting the Basel III Accord framework in 2010.26 Similarly, the Financial Stability Board ${ }^{27}$ has indicated in its Enhancing Market and Institutional Resilience Report the need for market transparency to restore and maintain confidence in the financial markets by encouraging financial institutions to develop appropriate rules on sharing trading information. ${ }^{28}$ In the same vein, the IASB recommended the adoption of the International Financial Reporting Standards to allow timeous disclosure of relevant financial information to the public and to all the relevant stakeholders. ${ }^{29}$ It is submitted that sharing such information will enable both the market participants and the regulatory authorities to promptly detect and prevent the occurrence of market abuse activities in the financial

${ }^{16}$ See further related comments in the IOSCO Objectives and Principles June 20105 <http://www.iosco.org/library/pbdocs/pdf /IOSCOPD329.pdfs (accessed 07-07-2013).

17 The IOSCO Task Force on Unregulated Financial Markets and Products Technical Committee Final Report 20099 $<$ http://www.iosco.org/library/pbdocs/pdf/IOSCOPD301.pdf > (accessed 07-07-2013).

18 See further related remarks in the IOSCO Objectives and Principles May 200342 <http://www.iosco.org/library /pbdocs/pdf/IOSCOPD154.pdf > (accessed 07-07-2011).

19 Paulo 2011 Fondation Robert Schuman 6 <http://www.robert-schuman.eu/frs-fichecrisefi-qe200-en.pdfs (accessed 04-07-2013).

20 See further Cinquegrana The Need for Transparency in Commodity and Commodity Derivatives Markets ECMI Research Report 3 December 2008 14-19.

21 The IOSCO Task Force on Unregulated Financial Markets and Products Technical Committee Final Report 2009 31<http://www.iosco.org/library/pbdocs/pdf/IOSCOPD301.pdfs (accessed 07-07-2013).

22 The IOSCO Task Force on Unregulated Financial Markets and Products Technical Committee Final Report 2009 31<http://www.iosco.org/library/pbdocs/pdf/IOSCOPD301.pdfs (accessed 07-07-2013).

${ }^{23}$ The IOSCO Task Force on Unregulated Financial Markets and Products Technical Committee Final Report 200932 <http://www.iosco.org/library/pbdocs/pdf/IOSCOPD301.pdf> (accessed 07-07-2013).

24 The IOSCO Task Force on Unregulated Financial Markets and Products Technical Committee Final Report 2009 31-32 $<$ <ttp://www.iosco.org/library/pbdocs/pdf//OSCOPD301.pdf> (accessed 07-07-2013).

25 The Basel Committee on Banking Supervision (BCBS) was formed in 1974 by the Group of Ten (G10) central bank governors as an international cooperation forum that deals with banking supervision.

${ }^{26}$ Kaufmann \& Weber 2010 Journal of International Economic Law 780; Paulo 2011 Fondation Robert Schuman 8 <http://www.robertschuman.eu/frs-fichecrisefi-qe200-en.pdfs (accessed 04-07-2013).

${ }^{27}$ The Financial Stability Board replaced the Financial Stability Forum which was formed by the Group of Seven (G7) finance ministers and central bank governors in 1999 to promote financial stability, see Paulo 2011 Fondation Robert Schuman 8 <http://www.robertschuman.eu/frs-fichecrisefi-qe200-en.pdfs (accessed 04-07-2013).

28 Kaufmann \& Weber 2010 Journal of International Economic Law 780.

${ }^{29}$ Kaufmann \& Weber 2010 Journal of International Economic Law 782. 
markets. ${ }^{30}$ Additionally, the WTO has various general rules on transparency under the General Agreement on Tariffs and Trade, the Agreement on Technical Barriers to Trade and the General Agreement on Trade in Services. ${ }^{31}$ For purposes of this sub-heading, only the General Agreement on Trade in Service's rules on transparency will be briefly discussed. The General Agreement on Trade in Services transparency rules, unlike those of the Bank for International Settlements, requires member states to publish all the relevant measures and review mechanisms on transparency. ${ }^{32}$ The General Agreement on Trade in Services further requires all market participants and relevant stakeholders to be given information on the applicable trade requirements before they enter into any agreement. ${ }^{33}$ Nevertheless, these transparency rules are not binding and they are only adopted by the WTO member states on a voluntary basis.

\subsubsection{Evaluation of the South African Anti-Market Abuse Enforcement Framework}

The Financial Services Board (the FSB), ${ }^{34}$ the Directorate of Market Abuse (the DMA), the Board of Appeal (the BOA) and the Enforcement Committee (the EC) do not have specific legally binding guidelines and rules on financial markets transparency. Apparently, financial markets transparency issues are dealt with by the Johannesburg Stock Exchange Limited (the JSE). Notably, the JSE requires all issuers of listed securities to timeously disclose non-public price-sensitive information relating to any securities to inter alia promote transparency in the regulated financial markets and to prevent market abuse practices. ${ }^{35}$ The JSE Listing Requirements further oblige issuers of securities to disclose information relating to trade statements and other activities that may affect the price of securities during or prior to their listing to prevent unusual price movements which could result in market abuse. ${ }^{36}$ Put differently, issuers of securities other than those who publish quarterly results ${ }^{37}$ are obliged to publish trading statements as soon as they are satisfied that a reasonable degree of certainty exists that the financial results for a period to be reported upon next will vary by at least $20 \%$ from the most recent of the financial results of the previous corresponding period or of a profit forecast previously provided to the market in relation to that period. ${ }^{38}$ This was probably intended at discouraging market abuse practices. Notably, before its consolidation into the JSE, the Bond Exchange of South Africa (the BESA) had its own market transparency rules and obligations, especially for inter-dealer brokers. ${ }^{39}$ In fact, the BESA Rules mandated inter-dealer brokers ${ }^{40}$ to disclose some information such as the identity, price of securities and the nature of securities transactions to enhance transparency in commodity derivatives markets. ${ }^{41}$ Additional measures were further employed by the BESA to mandate a market association to enforce sound trading standards such as the central discovery system to increase transparency and stability in the financial markets. ${ }^{42}$ In spite of this, it remains to be seen whether these BESA transparency rules are going to continue to be utilised and employed by the JSE to curb market abuse activity, especially in over the counter transactions and commodity derivatives markets.

It is submitted that the FSB should consider establishing its own mandatory legally binding guidelines on market transparency to prevent relevant trading information asymmetry problems associated with issuers and market abuse activity. It is further acknowledged that the JSE Listing Requirements have addressed some aspects of market transparency to a fair extent but nonetheless it is suggested that the determination of a reasonable degree of certainty in

\footnotetext{
30 Kaufmann \& Weber 2010 Journal of International Economic Law 782.

31 Kaufmann \& Weber 2010 Journal of International Economic Law 786.

32 Kaufmann \& Weber 2010 Journal of International Economic Law 786.

${ }_{33}$ Kaufmann \& Weber 2010 Journal of International Economic Law 786.

34 The FSB may only require the regulated markets to adopt relevant measures to effectively monitor and detect market abuse violations after prior consultation with such markets and it may disclose the status or final outcome of its investigations if such disclosure is in the public interest, see s 84(2)(e) \& (g) of the Financial Markets Act. However, this provision does not expressly empower the FSB to make mandatory binding rules on market transparency to combat market abuse activity in the South African financial markets.

$35 \mathrm{~S} 3$ of the JSE Listing Requirements.

${ }^{36} S 3.4$ of the JSE Listing Requirements.

${ }_{37}$ These issuer must comply with s 3.4(b)(i) to (vi) of the JSE Listing Requirements while those who publish quarterly results must comply with s 3.4(b)(vii) and may elect to comply with s 3.4(b)(i) to (vi) of the JSE Listing Requirements. It is however submitted that this disparity on the part of the issuers' requirements could weaken the JSE's market transparency regulation.

38 S 3.4(b) of the JSE Limited Listing Requirements.

39 See BESA Rule D.13.

40 These are registered authourised users who act as matched principals (facilitators) in securities transactions between such authorised users and their clients in accordance with the relevant markets as provided in the BESA Rules.

${ }^{41}$ BESA Rules D13.1.1.1.1; D13.1.1.1.2 \& D13.1.1.1.3.

42 BESA Rule C1.1.3.3; also see Swart The Legal Framework Pertaining to Selected Segments of the Financial Market 120.
} 
terms of these Listing Requirements should not be only contingent upon the issuers of listed securities and their directors to avoid possible subjectivity and/or bias which could hamper the market transparency enforcement efforts of the JSE. ${ }^{43}$ It is also suggested that the JSE should continue to promote the BESA Rules on market transparency to discourage market abuse practices in commodities derivatives markets. Additionally, the JSE should adopt new secondary market trading report systems in line with those proposed by the IOSCO to enable all relevant persons to timeously have accurate trading information relating to both listed securities and over the counter transactions. ${ }^{44}$ In relation to this, both the FSB and the JSE should carefully develop additional viable measures for the clearing of over the counter commodities and commodities derivatives transactions as recommended by the IOSCO. ${ }^{45}$ These measures could increase the sharing of trading information and market transparency in unregulated over the counter commodities and commodities derivatives markets. ${ }^{46}$

The Financial Markets Act does not have a provision that specifically enforces market transparency best practices in relation to over the counter commodities and derivatives markets. This Act does, however, require exchange rules to provide efficient, honest, transparent and fair measures in which, and terms and conditions subject to which transactions in listed securities must be effected by authorised users, whether for own account or on behalf of other persons. ${ }^{47}$ Be that as it may, this requirement still does not directly address issues on market transparency in over the counter commodities and derivatives markets. In an attempt to increase financial markets transparency, the Financial Markets Act obliges financial institutions to disclose their transactions in listed securities to the Registrar of Securities if they result in a change of beneficial ownership in relation to such securities or to those concluded not via an exchange. ${ }^{48}$ In turn, the Registrar of Securities is required to disclose such transactions to the relevant exchange and to the public unless if the disclosure will be contrary the objects of the Financial Markets Act. ${ }^{49}$ This provision did not, however, provide clear guidelines regarding the reporting of transactions which could give rise to a change of beneficial ownership outside of an exchange. However, the Financial Markets Act tackles this obscurity by providing that only principal trades in listed securities between financial institutions ${ }^{50}$ and corporate actions concluded outside of an exchange and resulting in a change of beneficial ownership of those securities must be reported to the Registrar of Securities by that financial institution or parties to the corporate action in question. ${ }^{51}$ The Financial Markets Act now expressly require the Registrar of Securities to disclose these transactions to the public only if such disclosure will promote regulatory effectiveness and/or market transparency. ${ }^{52}$ Despite this, the Financial Markets Act, like the Securities Services Act, ${ }^{53}$ omit to impose a mandatory obligation on the exchange or the JSE to publish any information disclosed to it to increase transparency in the financial markets. ${ }^{54}$

\subsection{Investor Due Diligence}

Investor due diligence can be defined to include appropriate measures such as internal standards or codes of conduct that must be observed by investors to enable them to have a proper understanding of the nature of transactions as well

\footnotetext{
${ }^{43}$ S 3.4(b)(i) of the JSE Listing Requirements.

44 See paragraph 2.1 .1 above.

${ }^{45}$ See paragraph 2.1.1 above; similarly in the US, the Treasury recommended the amendment of the federal commodities and securities laws to accommodate a clearing system of all standardised over the counter (OTC) derivatives by the central counterparties, see the US Treasury Financial Regulatory Reform, A New Foundation: Rebuilding Financial Supervision and Regulation Report 17 June 2009 ; see further the IOSCO Task Force on Unregulated Financial Markets and Products Technical Committee Final Report 200935 $<$ http://www.iosco.org/library/pbdocs/pdf/IOSCOPD301.pdf> (accessed 07-07-2013).

${ }^{46}$ Although the Financial Markets Act provides for the establishment of a clearing house to assist an exchange with settlement and clearing services as well as the establishment of a central securities depository, it did not expressly provide for market transparency particularly in OTC transactions. See ss 48 \& 49 read with ss 30; 38 \& 42 of the Financial Markets Act.

$47 S 17(2)(d)$.

48 S 25(1) \& (2).

$49 S 25(3)$.

${ }^{50}$ As defined in see $s 1$ of the Financial Markets Act to include organisations such as collective schemes, pension funds, friendly societies and banks.

51 S 25(1); (2) \& (3)(a).

$52 S 25(3)(b)$.

$53 S 21(4)$.

54 S 25(4) of the Financial Markets Act.
} 
as the risks involved before they venture into any investment opportunity. ${ }^{55}$ Given the impact of the recent global financial crisis, it is prudent to investigate the gaps exposed by this crisis in relation to investor due diligence. ${ }^{56}$

\subsubsection{Overview of the International Best Practice}

Several institutions and investors did not embrace the notion of investor due diligence; instead they depended too much on credit rating agencies. ${ }^{57}$ This led international organisations like the IMF58 to recommend that regulators should adopt strict measures to encourage less reliance on the credit rating agencies by investors and the relevant financial institutions ${ }^{59}$ In other words, the IMF proposed that member states should develop interventions to encourage investor due diligence before commencing with the rescue or bailout process of the affected financial institutions. ${ }^{60}$ The Financial Stability Board also stipulates that the flaws in investor due diligence regulation should be addressed. ${ }^{61}$ Specifically, the Financial Stability Board submits that investor due diligence should be employed particularly in credit default swaps transactions. ${ }^{62}$ If correctly enforced, this recommendation could curb operational risks and market abuse activity in the financial markets. Other organisations like the World Bank, the Group of Thirty (the G30), the Group of Twenty (the G20) and the United States Senate Congressional Oversight Panel have further reiterated the need to revisit investor due diligence rules and regulations to avert possible systemic risks and other related problems. ${ }^{63}$ Additionally, the $10 S C O$ Technical Committee, Standing Committee 5 on Investment Management was formulated to review the degree at which investment managers who offer collective investment schemes to retail investors have invested in structured financial products. ${ }^{64}$ This committee was also tasked to investigate the type and degree of due diligence employed by such investors and investment managers. ${ }^{65}$ Lastly, this committee was mandated to review the measures, if any, taken by the investment managers to protect retail investors from incurring losses in their structured financial products during the global financial crisis. ${ }^{66}$ In July 2009, the IOSCO published its Good Practices in Relation to Investment Managers' Due Diligence When Investing in Structured Finance Instruments guidelines which advocate for the establishment and enforcement of adequate systems by all investors in order for them to understand whatever transactions and investment financial products they trade in ${ }^{67}$ Despite this, these guidelines were still restricted to structured financial products and other types of financial instruments remain unregulated. Consequently, some of the flaws that were exposed by the

55 The IOSCO Task Force on Unregulated Financial Markets and Products Technical Committee Final Report 20099 $<$ http://www.iosco.org/library/pbdocs/pdf/IOSCOPD301.pdfs (accessed 07-07-2013); see further analysis and related remarks in the IOSCO The Subprime Crisis Final Report May 20089 \& $10<$ http://www.iosco.org/library/pubdocs/pdf/IOSCOPD273.pdf> (accessed 2108-2011).

56 The IOSCO Task Force on Unregulated Financial Markets and Products Technical Committee Final Report 2009 9; also see generally the IOSCO The Subprime Crisis Final Report May $200813<$ http://www.iosco.org/library/pubdocs/pdf/IOSCOPD273.pdf> (accessed 2108-2011) \& related discussion by the IMF "The Initial Lessons of the Global Financial Crisis" 2009 <http://www.imf.org lexternal/np/pp/eng/2009/020609.pdfs (accessed 09-07-2011).

57 Paulo 2013 Fondation Robert Schuman 13 <http://www.robert-schuman.eu/frs-fichecrisefi-qe200-en.pdf> (accessed 04-07-2013).

58 The IMF was set up by the Bretton Woods Agreements in 1944 initially to ensure the proper functioning of the Bretton Woods monetary regime, see Paulo 2011 Fondation Robert Schuman 7-8 <http://www.robert-schuman.eu/frs-fichecrisefi-qe200-en.pdfs (accessed 04-07-2013).

${ }^{59}$ The IMF 2009 <http://www.imf.org/external/np/pp/eng/2009/020609.pdf> (accessed 09-07-2011).

60 This is might be targeted at preventing the recurrence of events and consequences that eventually led to the bankruptcy of Lehman Brothers in the US. See Kaufmann \& Weber 2010 Journal of International Economic Law 781.

${ }^{61}$ Financial Stability Board FSF Working Group on Market and Institutional Resilience Preliminary Report to the G7 Finance Ministers and Central Bank Governors October 2007 3, electronically available and accessible at <http://www.financialstabilityboard.org /publications/r_0710a.pdf > (accessed 22-08-2011).

62 Financial Stability Forum Financial Stability Forum on Enhancing Market and Institutional Resilience Report 7 April 2008 21; the G20 Study Group G20 Study Group on Global Credit Market Disruptions 31 October 200848.

63 The IOSCO Task Force on Unregulated Financial Markets and Products Technical Committee Final Report 200912 <http://www.iosco.org/library/pbdocs/pdf/IOSCOPD301.pdf > (accessed 07-07-2013).

64 The IOSCO Task Force on Unregulated Financial Markets and Products Technical Committee Final Report 200910 $<$ http://www.iosco.org/library/pbdocs/pdf/IOSCOPD301.pdf > (accessed 07-07-2013).

65 The IOSCO Task Force on Unregulated Financial Markets and Products Technical Committee Final Report 2009 10<http://www.iosco.org/library/pbdocs/pdf/IOSCOPD301.pdf > (accessed 07-07-2013).

66 The IOSCO Task Force on Unregulated Financial Markets and Products Technical Committee Final Report 200910 <http://www.iosco.org/library/pbdocs/pdf/IOSCOPD301.pdf > (accessed 07-07-2013).

${ }^{67}$ For further analysis, see the IOSCO Good Practices in Relation to Investment Managers' Due Diligence When Investing in Structured Finance Instruments July 2009 <http://www.iosco.org/library/pubdocs/pdf/IOSCOPD300.pdf> (accessed 21-08-2013). 
global financial crisis, for instance in the securitisation process and the barriers to effective investor due diligence regulation, have remained largely unresolved. 68

\subsubsection{Evaluation of the South African Anti-Market Abuse Enforcement Framework}

The market abuse provisions contained in the Financial Markets Act do not expressly regulate matters involving investor due diligence. ${ }^{69}$ Enforcement of investor due diligence standards is apparently left to the issuers of securities and investors themselves to develop their own guidelines and then abide by such guidelines. However, the Financial Markets Act merely impose some general requirements on clearing house license holders to ensure that the "fit and proper requirements" prescribed by the Registrar of Securities Services are met by the applicant, its directors and senior management. ${ }^{70}$ No specific provision is made for the clearing house license holders to mandate their applicants and/or investors to comply with investor due diligence best practice guidelines. In relation to this, the Financial Markets Act should be amended to accommodate new adequate provisions specifically dealing with investor due diligence to prevent market abuse and other possible financial risks in the South African financial markets. It is further submitted that the aforementioned provisions should be carefully drafted to include unambiguous and practical investor due diligence measures which must be mandatorily observed by all investors, issuers of securities and other relevant market participants. These measures must expressly discourage financial institutions, investors, the JSE and other relevant persons from over-relying on credit rating agencies and must stipulate appropriate penalties to be imposed on the offenders in line with the IOSCO proposals. ${ }^{71}$ Giving due regard to the applicable IOSCO Good Practices in Relation to Investment Managers' Due Diligence When Investing in Structured Finance Instruments guidelines, ${ }^{72}$ it is hoped that a specific statute solely dealing with market transparency, issuer transparency and investor due diligence will be enacted in future to enhance and enable the FSB and the JSE to enforce investor due diligence best practices and to curb systemic risks and possible cross-border market abuse activity in the South African financial markets.

\subsection{Issuer Transparency}

As opposed to market transparency, ${ }^{73}$ issuer transparency can be defined to include the degree or extent at which relevant non-public price-sensitive information relating to securities or financial instruments is accurately and timeously disclosed by the issuers of such securities or financial instruments to the financial markets, investors and other relevant persons. During the global financial crisis, the IOSCO published its Subprime Crisis Final Report which argued that the global financial crisis was caused, in part, by flawed and lax enforcement of issuer transparency rules. ${ }^{74}$

\subsubsection{Overview of the International Best Practice}

After the global financial crisis, the IOSCO established a Technical Committee, Standing Committee 1 on Multinational Disclosure and Accounting to review the adequacy and enforcement of issuer transparency as well as investor due diligence guidelines. ${ }^{75}$ This Committee recommended the development of new principles pertaining to the disclosure requirements for public offerings of asset-backed securities in order to align the IOSCO issuer disclosure guidelines to the ever-changing financial economic climate and to address the challenges posed by the global financial crisis. ${ }^{76}$ The

68 The IOSCO Task Force on Unregulated Financial Markets and Products Technical Committee Final Report 200916 $<$ http://www.iosco.org/library/pbdocs/pdf/IOSCOPD301.pdf > (accessed 07-07-2013).

${ }^{69}$ See ss 77; 78; 80; 81 \& 82 and related provisions under Chapter $X$ of the Financial Markets Act.

70 See $s 48(1)(c)$.

${ }^{11}$ See the IOSCO The Subprime Crisis Final Report May $20089 \& 10<$ <ttp://www.iosco.org/library/pubdocs/pdf/IOSCOPD273.pdfs (accessed 21-08-2011).

72 The IOSCO Task Force on Unregulated Financial Markets and Products Technical Committee Final Report 200910 <http://www.iosco.org/library/pbdocs/pdf/IOSCOPD301.pdfs (accessed 07-07-2013); also see paragraph 2.2.1 above.

${ }^{73}$ See paragraph 2.1 above.

74 See further analysis in the IOSCO The Subprime Crisis Final Report May 20087 <http://www.iosco.org/library/pubdocs /pdf/IOSCOPD273.pdf> (accessed 21-08-2011).

75 The IOSCO Task Force on Unregulated Financial Markets and Products Technical Committee Final Report 20099 $<$ <ttp://www.iosco.org/library/pbdocs/pdf/IOSCOPD301.pdf > (accessed 07-07-2013).

76 The IOSCO Task Force on Unregulated Financial Markets and Products Technical Committee Final Report 20099 $<$ http://www.iosco.org/library/pbdocs/pdf/IOSCOPD301.pdf > (accessed 07-07-2013). 
IOSCO established a Technical Committee, Standing Committee 2 on Regulation of Secondary Markets which also recommended that issuers should be encouraged to develop their own additional guidelines and internal disclosure requirements to increase post-trade transparency, particularly in structured financial products. ${ }^{77}$ As is the case in the US, the IOSCO recommended that such disclosure requirements must be applicable whenever an issuer makes a public offering, irrespective of whether the financial products in questions are listed on a regulated financial market or traded in over the counter markets. ${ }^{78}$ Furthermore, the IOSCO, on behalf of the Financial Stability Board, recommended that issuers and other market participants should provide full, accurate and prompt disclosure of their financial results, possible trading risks and any information which could be relevant to the investors and other interested persons. ${ }^{79}$ According to the IOSCO, failure to comply with any of the disclosure guidelines and requirements could attract appropriate administrative ${ }^{80}$ criminal and civil sanctions on the part of the offenders..$^{81}$ Notably, these penalties will not be imposed on issuers in event of their non-disclosure of certain information to protect trade secrets or where such disclosure could be detrimental to the investors concerned. ${ }^{82}$ The IOSCO further recommended that issuers should be mandated to disclose all the relevant information on securities or related financial transactions, including initial and ongoing information pertaining to such transactions. ${ }^{83}$

The G20 published a document entitled the G-20 Working Group on Enhancing Sound Regulation and Strengthening Transparency ${ }^{84}$ which provided a general roadmap and guidelines to be adopted by issuers to promote greater transparency, particularly in the over the counter markets. This could have been targeted at combating market abuse and other illegal trading practices in the over the counter markets. Lastly, the European Securitisation Forum published its Residential Mortgage-Backed Securities Issuer Principles for Transparency and Disclosure Principles ${ }^{85}$ to enhance and enforce consistency and ongoing transparency by issuers to investors across the European Union (the EU) member states. ${ }^{86}$

\subsubsection{Evaluation of the South African Anti-Market Abuse Enforcement Framework}

There is no legislation that solely regulates issuer transparency standards in South Africa. Furthermore, the Financial Markets Act's market abuse provisions do not specifically stipulate any rules or regulations pertaining to issuer transparency. This Act nonetheless in-exhaustively deals with some of the issues that relate to issuer transparency. For example, it requires an exchange to make listing requirements with which issuers of listed securities and of securities which are intended to be listed, as well as such issuers' agents, must comply; ${ }^{87}$ the standards of conduct that issuers of listed securities and their directors, officers and agents must meet ${ }^{88}$ and the standards of disclosure and corporate

77 The IOSCO Task Force on Unregulated Financial Markets and Products Technical Committee Final Report 20099 $<$ http://www.iosco.org/library/pbdocs/pdf/IOSCOPD301.pdf > (accessed 07-07-2013).

78 The IOSCO Task Force on Unregulated Financial Markets and Products Technical Committee Final Report 200913 $<$ http://www.iosco.org/library/pbdocs/pdf/IOSCOPD301.pdf > (accessed 07-07-2013).

79 Generally see the IOSCO Objectives and Principles June $20108<$ <ttp://www.iosco.org/library/pbdocs/pdf/IOSCOPD329.pdf > (accessed 07-07-2013).

80 Such administrative sanctions could include suspensions from trading, injunctions and mandatory court orders to disclose the required information to investors.

81 Generally see the IOSCO Objectives and Principles May $200324<$ <ttp://www.iosco.org/library/pbdocs/pdf/IOSCOPD154.pdf > (accessed 07-07-2011).

82 Generally see the IOSCO Objectives and Principles May $200324<$ <ttp://www.iosco.org/library/pbdocs/pdf//OSCOPD154.pdf > (accessed 07-07-2011).

83 The IOSCO Task Force on Unregulated Financial Markets and Products Technical Committee Final Report 20099 <http://www.iosco.org/library/pbdocs/pdf/IOSCOPD301.pdf > (accessed 07-07-2013).

84 See related proposals in the G20 London Summit Communiqué which can be accessed at <http://www.g20.org/Documents Ig20_communique_020409.pdf> (accessed 17-06-2011); also see the IOSCO Task Force on Unregulated Financial Markets and Products Technical Committee Final Report 20099 <http://www.iosco.org/library/pbdocs/pdf//OSCOPD301.pdf > (accessed 07-072013).

85 This was largely influenced by the Ten Industry Initiatives to Increase Transparency in the European Securitisation Markets released by nine European and global trade associations; also see the IOSCO Task Force on Unregulated Financial Markets and Products Technical Committee Final Report 200923 <http://www.iosco.org/library/pbdocs/pdf/IOSCOPD301.pdf > (accessed 07-07-2013).

86 Also see the American Securitisation Forum's Project Restart Proposals at <http://www.americansecuritization.com /story. aspx?id=2657> (accessed 08-08-2013).

$87 \mathrm{~S} \mathrm{11(1)(b).}$

$88 \mathrm{~S} 11(1)(c)$. 
governance that issuers of listed securities must meet. ${ }^{89}$ Despite this, the Financial Markets Act does not provide sufficient clarity on whether the stated standards of conduct and/or standards of disclosure and corporate governance with which the issuers of listed securities are required to comply refer also to issuer transparency standards. Nonetheless, the Financial Markets Act provides that the issuers of listed securities may be mandated by an exchange to disseminate certain information where such dissemination is necessary to achieve the objects of this Act. ${ }^{90}$ Where the issuer unduly withhold information or refuses to disclose information to the exchange and/or the registered holder of securities, the exchange may temporarily suspend trading in those securities until the disclosure is made. ${ }^{91}$ While this measure may assist the exchange to prevent possible market abuse activities, it is submitted that a fixed time period for such suspension of trading in the affected securities should have been clearly stipulated in the Financial Markets Act to encourage more compliance on the part of the issuers of listed securities. On the other hand, when the issuer of listed securities discloses information that could affect the prices of securities to the registered holders of securities, the issuer concerned is required to make the information in question available immediately to the public. ${ }^{92}$ If successfully complied with, this provision may aid the FSB, the JSE and other enforcement authorities in curbing market abuse practices in the South African financial markets.

Additionally, the Financial Markets Act now only permits the DMA to share information concerning any market abuse or related matter with the Takeover Regulation Panel, the South African Reserve Bank, the Independent Regulatory Board for Auditors, all self-regulatory organisations, the Financial Intelligence Centre, the National Treasury, the Finance Minister and with the persons, whether inside the Republic or elsewhere, responsible for regulating, investigating or prosecuting insider trading, prohibited trading practices and other market abuse activities. ${ }^{93}$ It is submitted that this provision could encourage issuer transparency and assist the FSB and other regulatory authorities in discouraging market abuse practices by issuers of securities and other persons who misuse non-public price-sensitive information for their own profit. The Financial Markets Act also introduced a trade repository which is obliged to employ timely and efficient record-keeping procedures; publish aggregate positions of classes of unlisted securities reported to it, including but not limited to, classes of derivatives contracts reported to it and make the necessary information available to the registrar of securities services and other relevant supervisory authorities. ${ }^{94}$ This mandatory duty on the part of the trade repository, to disclose required information to the registrar of securities services and where applicable, to the public may give rise to the effective transparent reporting of relevant trading information including over the counter derivatives transactions relating to the issuer of securities.

In addition, the issuer transparency issues are dealt with in the Listing Requirements of the JSE which enables it, when it is deemed to be in the public interest, to request by notice in writing, that all applicant issuers publicly disclose all the information as disclosed to registered holders of securities and the financial markets. ${ }^{95} \mathrm{An}$ applicant issuer is further required to publish any other information not specified in the JSE Listing Requirements in appropriate format and within a specified time period. ${ }^{96}$ Failure to comply with this requirement will result in the JSE publishing the information in question after having heard the applicant issuer's representations or after having given that issuer the opportunity to make representations. ${ }^{97}$ This provision was most likely targeted at discouraging issuers of listed securities from concealing material non-public information which, when later published, will have a negative effect on the price of the securities concerned, possibly because of market abuse activities. The same provision does not, however, clearly stipulate the conditions for protecting confidential information such as trade secrets and penalties that could be imposed on issuers who unduly refuse to comply with the issuer disclosure requirements. The JSE's Equity Rules further require all its members to provide their clients with accurate, ${ }^{98}$ correct, ${ }^{99}$ unambiguous ${ }^{100}$ and adequate ${ }^{101}$ information regarding

\footnotetext{
${ }^{89} S 11(1)(d)$.

$91 \mathrm{~S} \mathrm{14(1)(c).}$

$92 S$ 14(2).

$93 \mathrm{~S} 88$.

${ }^{94} S 57$ read with s 58 .

${ }^{95} S 1.25$ of the JSE Listing Requirements.

${ }^{96}$ S 1.26 of the JSE Listing Requirements.

${ }^{97} \mathrm{~S} 1.26$ of the JSE Listing Requirements.

${ }^{98} S$ 8.10.3.1.2 of the JSE Equity Rules.

${ }^{99} S$ 8.10.3.1.1 of the JSE Equity Rules.

100 S 8.10.3.1.2 of the JSE Equity Rules.

101 S 8.10.3.1.3 of the JSE Equity Rules.
}

${ }^{90}$ An exchange may oblige the issuer of securities to disclose any information pertaining to the securities in question and/or trading history of that issuer to registered holders of securities within a period specified by the exchange, see s 14(1)(a) \& (b). 
relevant aspects like fees, remuneration, values, charges and sums that are not objectively predetermined. ${ }^{102}$ Put simply, the JSE Equity members are required to disclose to their clients and/or investors accurate and adequate information, excluding confidential information acquired from other clients unless consent is given by such clients concerning charges, fees, prohibited disclosures or restrictions placed on certain information. ${ }^{103}$ This provision will, if effectively enforced, increase issuer transparency in the South African financial markets. It is further suggested that the BESA Listing Disclosure Requirements which required investors to disclose information regarding the nature and state of business should be carefully amended and fused with the JSE Equity Rules to promote issuer transparency even in the over the counter commodities derivatives transactions to combat market abuse.

The Financial Advisory and Intermediary Services Act ${ }^{104}$ proposed the drafting and adoption of a code of conduct which provides for adequate disclosure of relevant information by the financial services providers and this code of conduct was published in 2003. ${ }^{105}$ The stated code of conduct requires financial services providers to disclose full and accurate information that would be expected to enable all investors and market participants to make informed decisions. ${ }^{106}$ Lastly, to remedy the flaws stated earlier, it is suggested that a specific legislation should be enacted in line with the IOSCO and the G20 proposals, to deal solely with issuer transparency, investor due diligence and market transparency in both the regulated and unregulated financial markets. ${ }^{107}$ This legislation must provide a mandatory continuous disclosure requirement on the part of the issuers for them to disclose initial and ongoing information pertaining to their securities ${ }^{108}$ to enable the FSB, the JSE and other relevant enforcement bodies to combat crossborder market abuse practices.

\subsection{Credit Rating Agencies}

Credit rating agencies perform, on behalf of investors and market participants, a pivotal role in credit worthiness assessment and the detection of various risks relating to investment instruments and/or financial products in order for such investors or market participants to make informed and sound investment decisions. ${ }^{109}$ Despite this, during the global financial crisis credit rating agencies' rating quality and models were found to be flawed because they could not detect risks, especially in relation to complex financial products and transactions in the over the counter financial markets. ${ }^{110}$

102 Ss 8.10.3.1.4 \& 8.10.3.1.5 of the JSE Equity Rules.

${ }^{103}$ Ss 8.10.3.2.1 to 8.10.3.2.3 of the JSE Equity Rules.

10437 of 2002; hereinafter referred to as the Financial Advisory and Intermediary Services Act.

${ }^{105}$ Also see the General Code of Conduct for Authorised Financial Services Providers and Representatives, as published in the FSB Notice 80 of 2003; also see ss 15(1) \& 16(1) of the Financial Advisory and Intermediary Services Act.

${ }_{106}$ S 3(1)(a) read with s 7(1) of the Financial Advisory and Intermediary Services Act. Likewise, the Consumer Protection Act 68 of 2008, hereinafter referred to as the Consumer Protection Act, seeks inter alia to protect consumers from dishonest issuers of services by requiring such issuers to disclose appropriate information to the members of the public to enable them to make informed decisions, $s 3$ of the same Act (a detailed discussion of all the provisions of this Act is beyond the scope of this article). Nevertheless, both the Financial Advisory and Intermediary Services Act and the Consumer Protection Act do not have provisions that expressly enforce issuer transparency standards, especially in the over the counter markets.

107 This legislation should further provide adequate measures that protect investors' confidential information like trade secrets as well as appropriate civil, criminal and administrative penalties that can be imposed against those that do not comply with such measures.

108 The IOSCO Task Force on Unregulated Financial Markets and Products Technical Committee Final Report 200928 <http://www.iosco.org/library/pbdocs/pdf/IOSCOPD301.pdfs (accessed 07-07-2013).

109 Verhelst "Addressing the Financial Crisis: The EU's Incomplete Regulatory Response" 2010 Egmont Institute for International Relations Paper 3911 <http://www.egmontinstitute.be.ep39.pdf> (accessed 08-07-2011); Swart The Legal Framework Pertaining to Selected Segments of the Financial Market 101.

110 Verhelst 201011 <http://www.egmontinstitute.be.ep39.pdts (accessed 08-07-2011); the IOSCO The Subprime Crisis Final Report May 200813 <http://www.iosco.org/library/pubdocs/pdf/IOSCOPD273.pdfs (accessed 21-08-2011). Credit rating agencies were reportedly falling short in relation to transparency regulation, mitigation of the conflicts of interest, corporate governance and the issuance of accurate and quality credit ratings, see IOSCO The Role of Credit Rating Agencies in Structured Finance Market Report March 20082 <http://www.iosco.org/library/pubdocs/pdf/OSCOPD263.pdfs (accessed 14-06-2011); Secretariat of the European Banking Committee "Financial Turbulence: Following Up the October 2007 Ecofin" <http://ec.europa.eu/internal_market /bank/docs/ebc/ebc170308_en.pdfs (accessed 14-07-2011) \& Schapiro Testimony before the Financial Crisis Inquiry Commission Concerning the State of the Financial Crisis 14 January 2010 115-16. 


\subsubsection{Overview of the International Best Practice}

The IOSC proposed that the financial institutions should meticulously adopt their own internal regulatory models to assess possible systemic financial risks and to be less dependent on credit rating agencies. ${ }^{111}$ Additionally, the IOSCO proposed that credit rating agencies should be adequately regulated to allow registration of their ratings and ongoing supervision so as to enhance greater oversight cooperation and information sharing among the regulatory authorities. ${ }^{112}$ The IOSCO published its Good Practices in Relation to Investment Managers' Due Diligence When Investing in Structured Finance Instruments ${ }^{113}$ guidelines which recommended the establishment of independent third parties other than credit rating agencies to evaluate risks in securitised products and monitor the rating methodologies of credit rating agencies in relation to securitised products. ${ }^{114}$ In another attempt to resolve various problems posed by credit rating agencies, especially with regard to accountability, transparency and misleading credit ratings relating to some financial products, a revised Code of Conduct Fundamentals for Credit Ratings Agencies was issued in 2008. ${ }^{115}$ This Code of Conduct further addresses issues pertaining to the responsibility of investment managers (their own due diligence) when using ratings; reliability and integrity of the rating process and independence and avoidance of conflicts of interest in the rating of structured products. ${ }^{116}$ Moreover, the IOSCO has reportedly completed an assessment of appropriate methodology for checking compliance with its Code of Conduct Fundamentals for Credit Ratings Agencies in September 2008 and has set out some measures to enhance the international monitoring and supervision of credit rating agencies. ${ }^{117}$ Likewise, the Global Joint Initiative ${ }^{118}$ recommended the adoption of relevant measures to restore market confidence in the credit rating agencies by increasing transparency in their rating process. ${ }^{119}$ The European Commission (the EC) has also published some guidelines for credit rating agencies dealing with matters that include improvement of transparency, corporate governance registration and the overall supervision of credit rating agencies. ${ }^{120}$ More specifically, these guidelines are entitled the European Union Regulation on Credit Rating Agencies and they are further targeted at mitigating possible conflicts of interest and increasing competition among the credit rating agencies. ${ }^{121}$ In

111 See further discussion and analysis in the IOSCO The Subprime Crisis Final Report May 200813 <http://www.iosco.org/library/pubdocs/pdf/IOSCOPD273.pdf> (accessed 21-08-2011); Paulo 2011 Fondation Robert Schuman 13 $<$ http://www.robert-schuman.eu/frs-fichecrisefi-qe200-en.pdf> (accessed 04-07-2013).

112 The IOSCO Task Force on Unregulated Financial Markets and Products Technical Committee Final Report 200911 <http://www.iosco.org/library/pbdocs/pdf/IOSCOPD301.pdfs (accessed 07-07-2013); also see the IOSCO Objectives and Principles June 20109 <http://www.iosco.org/library/pbdocs/pdf/IOSCOPD329.pdf > (accessed 07-07-2013).

113 See the IOSCO Good Practices in Relation to Investment Managers' Due Diligence July 2009 <http://www.iosco.org/library/pubdocs /pdf/IOSCOPD300.pdf> (accessed 21-08-2013).

114 This recommendation seeks to promote less reliance on credit rating agencies by companies and other financial institutions by inter alia discouraging lax regulation of these agencies. See generally the IOSCO Task Force on Unregulated Financial Markets and Products Technical Committee Final Report 200925 <http://www.iosco.org/library/pbdocs/pdf//OSCOPD301.pdf> (accessed 07-072013) \& further related remarks and recommendations in the IOSCO The Role of Credit Rating Agencies Report March 20082 $<$ http://www.iosco.org/library/pubdocs/pdf/IOSCOPD263.pdfs (accessed 14-06-2011).

115 See the IOSCO Task Force on Unregulated Financial Markets and Products Technical Committee Final Report 2009 11; 20 \& 22 <http://www.iosco.org/library/pbdocs/pdf/IOSCOPD301.pdfs (accessed 07-07-2013); also see the IOSCO Objectives and Principles June 20109 <http://www.iosco.org/library/pbdocs/pdf//OSCOPD329.pdf> (accessed 07-07-2013) \& D'Aloisio speech to the Australian Corporate Lawyers Association entitled The New ASIC: Addressing Today's Challenges and Building for the Longer Term 7 November 2008 15-16.

${ }_{116}$ D'Aloisio speech entitled The New ASIC: Addressing Today's Challenges and Building for the Longer Term 7 November 200815 \& see further analysis in the Secretariat of the European Banking Committee article <http://ec.europa.eu/internal_market /bank/docs/ebc/ebc170308_en.pdf> (accessed 14-07-2011).

117 The IOSCO IOSCO Urges Greater International Coordination in the Oversight of Credit Rating Agencies, IOSCO Media Release 011/2008 17 September 2008; D'Aloisio speech entitled The New ASIC: Addressing Today's Challenges and Building for the Longer Term 7 November 2008 15-16; D'Aloisio Securities Markets, Participants and ASIC (2008) paper presented at the Securities \& Derivatives Industry Association Conference 2008-05-22 18.

118 Comprises of the American Securisation Forum (ASF), Securities Industry \& Financial Markets Association (SIFMA), Australian Securitisation Forum (AuSF) \& the European Securitisation Forum (ESF).

119 Global Joint Initiative Report 63.

120 See generally Bake, Hawken \& Parker "The EU Regulation of Credit Rating Agencies Approved" <http://www.mayerbrown.com /publications/articles.asp?id=6529\&nid=6> (accessed 12-06-2011).

121 See further Paulo 2011 Fondation Robert Schuman 13 <http://www.robert-schuman.eu/frs-fichecrisefi-qe200-en.pdf> (accessed 0407-2013). 
addition, the EC published a document entitled Driving European Recovery ${ }^{122}$ which seeks to improve the confidence in the European financial markets through the enforcement of adequate rules that regulate credit rating agencies. In 2009, the EU adopted a specific regulation which set out certain requirements for transparency and internal review mechanisms which must be complied with by credit rating agencies across Europe. ${ }^{123}$ The initial regulation of 2009 was further revised in June 2010 to strengthen the supervision of credit rating agencies by giving a more central enforcement role to the European Securities and Markets Authority (the ESMA) to supervise credit rating agencies across Europe. ${ }^{124}$ This proposal allows the ESMA to obtain information from issuers of structured financial instruments about their credit rating agencies transactions in order to discourage non-disclosure of unrequested ratings; temporarily prohibit or suspend the issuing of credit ratings by a specific credit rating agency and to impose pecuniary penalties upon the offenders. ${ }^{125}$ The EC reportedly proposed another revision of the credit rating agencies rules in a bid to resolve the financial challenges in Greece, Portugal, Spain, Ireland and Italy by, for instance, creating a single European Rating Agency. 126

The G20 has endorsed the IOSCO's proposals for credit rating agencies regulation and further proposed the development of new independent models for surveillance and coordination of the oversight regulation of credit rating agencies. ${ }^{127}$ In the same light, the Financial Stability Board issued its own proposal document entitled Principles for Reducing Reliance on Credit Rating Agencies which discourages the perverse complexity of credit ratings through the development of effective internal credit risk management policies. ${ }^{128}$ As indicated above, some investors, financial institutions and regulatory authorities relied too heavily on credit rating agencies without carefully evaluating the information given by these agencies regarding the AAA rated securities which eventually led to the financial collapse of Merrill Lynch, Lehman Brothers, AIG and other companies. ${ }^{129}$ Flawed financial models employed by credit rating agencies and the overall credit rating agencies regulation, especially in the US, contributed to the recent global financial crisis. ${ }^{130}$ Consequently, in an attempt to solve this problem, the US has downgraded its credit rating agency standards from AAA to AA+.

\footnotetext{
122 See the EC Driving European Recovery 4 March 2009 Final Com 114 7-8; Verhelst 20103 <http://www.egmontinstitute.be.ep39.pdfs (accessed 08-07-2011).

123See the EC Regulation 1060/2009 of 16 September 2009, (OJ L 302), 17.11.2009 1-31; Verhelst 201011 <http://www.egmontinstitute .be.ep39.pdfs (accessed 08-07-2011).

${ }_{124}$ Verhelst $201012<$ <htp://www.egmontinstitute.be.ep39.pdf> (accessed 08-07-2011).

125 Verhelst 201012 <http://www.egmontinstitute.be.ep39.pdfs (accessed 08-07-2011); see further Paulo 2011 Fondation Robert Schuman 13 <http://www.robert-schuman.eu/frs-fichecrisefi-qe200-en.pdfs (accessed 04-07-2013) \& European Commission Public Consultation on Credit Rating Agencies 5 November 2010.

126 Vander Stichele "EU Financial Reform: Some Small Steps, but no Fundamental Changes in Sight" (2010) <http://somo.nl/dossiersen/sectors/financial/eu-financial-reforms/newsletters> (accessed 08-07-2013); Paulo 2011 Fondation Robert Schuman 13 <http://www.robert-schuman.eu/frs-fichecrisefi-qe200-en.pdfs (accessed 04-07-2013). Other reforms introduced in the EU include the establishment of three main European Supervisory Authorities namely the European Banking Authority, the European Insurance \& Occupational Pensions Authority \& the ESMA which now oversees the enforcement of market abuse in the EU member states.

${ }^{127}$ See the Group of Twenty (G20) "The Global Plan for Recovery and Reform 2 April 2009" <http://www.g20.org/Documents/finalcommunique.pdfs (accessed 27-08-2011); also see recommendation 5 by the G20 Working Group 1 Enhancing Sound regulation and Strengthening Transparency Final Report 25 March 2009 6-10.

${ }^{128}$ It is submitted that this proposal will reduce biased credit ratings and assist regulators in preventing market abuse. See Financial Stability Board "Principles for Reducing Reliance on CRA Ratings" <http://www.financialstabilityboard.org/publications/r_101027.pdts (accessed 12-06-2011); Nanto The Global Financial Crisis: Analysis and Policy Implications Congressional Research Service Report (02-10-2009) 34 <http://www.crc.gov/congressional/Research/Service/Report.RL34742.pdf> (accessed 12-07-2013).

129 The US Senate Permanent Subcommittee on Investigations Wall Street and the Financial Crisis: Anatomy of a Financial Collapse Majority and Minority Staff Report 13 April 2011 249-255; Mazumder \& Ahmed "Greed, Financial Innovation or Laxity of Regulation? A Close Look into the 2007-2009 Financial Crisis and Stock Market Volatility" 2010 Studies in Economics \& Finance 110 118-119.

130 The global financial crisis was characterised by corporate fraud, insider trading, market manipulation and other related market abuse practices. For instance, Moody's Investors Service Inc \& Standard \& Poor's Financial Services LLC (S\&P) gave misleading AAA ratings for residential mortgage backed securities which later plummeted and contributed in part to the global financial crisis. See the US Senate Permanent Subcommittee on Investigations Wall Street and the Financial Crisis 243-256; also see generally Buiter Lessons From the Global Financial Crisis for Regulators and Supervisors (2009) paper presented at the Global Financial Crisis: Lessons and Outlook Workshop, at Kiel, 2009-05-8 6-8.
} 


\subsubsection{Evaluation of the South African Anti-Market Abuse Enforcement Framework}

There is no specific market abuse provision in the Financial Markets Act ${ }^{131}$ and the Companies Act ${ }^{132}$ that regulates and enforces credit rating agencies standards. The Financial Markets Act, however, proposes the establishment of independent clearing houses ${ }^{133}$ and trade repositories ${ }^{134}$ to provide adequate licensing procedures, internal controls and general requirements with which the trade repositories and clearing house members must comply, so as to protect investors by increasing the reliability, confidentiality and integrity of the trading information they receive from all the financial markets and/or other relevant market participants. Apparently, the independent clearing houses and trade repositories may impliedly perform some functions of credit rating agencies under the Financial Markets Act. However, trade repositories are precluded from outsourcing any of their operational functions without the prior written approval of the registrar of securities services. ${ }^{135}$ While this may prevent conflicts of interests, it is submitted that investors should not over-rely on trade repositories alone to avoid making subjectively influenced investment trading decisions. Moreover, there is no specific regulatory body in both the Financial Markets Act and the Companies Act 2008 that oversees the regulation of credit rating agencies. Thus, unlike the position held in other international jurisdictions like the US, Australia and the EU, where the US Securities and Exchange Commission, the Australian Securities and Investments Commission and the ESMA regulate and enforce credit rating agencies standards respectively, credit rating agencies are selfregulated in South Africa. ${ }^{136}$ Consequently, it remains uncertain whether this self-regulation is comparable to the international best practices pertaining to credit rating agencies. In fact, the Banking Sector Education and Training Authority contends that some standards provided in the IOSCO' Code of Conduct Fundamentals for Credit Ratings Agencies might be complexly difficult to implement in South Africa because compliance with this Code of Conduct is merely contingent upon the self-regulatory organisations themselves. ${ }^{137}$ In relation to this, the South African Finance Minister proposed that a Credit Rating Services Bill ${ }^{138}$ should be drafted in line with the G20 recommendations. ${ }^{139}$ Nonetheless, it is submitted that the Credit Rating Services Act should also have been drafted in accordance with the applicable proposals in the IOSCO' Code of Conduct Fundamentals for Credit Ratings Agencies and the Financial Stability Board's Principles for Reducing Reliance on Credit Rating Agencies proposals. ${ }^{140}$ However, it is important to note that the Credit Rating Services Act have some provisions that deal indirectly with credit rating agencies' transparency and that prohibit such agencies from engaging in other related financial services activities to avoid conflicts of interest. ${ }^{141}$ It is submitted that the Credit Rating Services Act should be amended to expressly provide for specific civil fines and administrative sanctions against the offenders. ${ }^{142}$ Additionally, the Credit Rating Services Act should also be applicable to private credit ratings of securities and financial instruments in both the regulated and unregulated financial markets to discourage market abuse activities in these markets.

\section{Concluding Remarks}

Although South Africa has made numerous efforts to combat market abuse practices, a lot may still need to be done to

131 See Chapter $X$ entitled market abuse.

13271 of 2008, hereinafter referred to as the Companies Act 2008.

133 Ss $50 \& 53$.

134 Ss 54 to 58 .

$135 S$ 56(4).

136 Swart The Legal Framework Pertaining to Selected Segments of the Financial Market 103. Therefore, it is submitted that the FSB or another independent regulatory body should be statutorily and expressly empowered to enforce the credit rating agencies standards in South Africa.

${ }^{137}$ Banking Sector Education and Training Authority "International Executive Developments Programme Europe 2009 Syndicate 2" $<$ http://www.bankseta.org.za/downloads/ssp/bankseta_presentation_(290709)_final.pdf> (accessed 12-06-2013).

138 [B-2011], hereinafter referred to as the Credit Rating Services Bill; also see s 2 of the Credit Rating Services Act 24 of 2012 , hereinafter referred to as the Credit Rating Services Act.

139 See the FSB Annual Report 2010 19; the South African Government Information "Medium Term Budget Policy Statement 2010 Speech by Pravin Gordhan Minister of Finance" <http://www.infor.gov.za/speech/DynamicAction?pageid=461\&sid=14081\&tid=23297> (accessed 28-08-2013).

140 See paragraph 2.4 .1 above.

141 Ss 12; 13; 14; 15 \& 16.

142 Ss 28; 30; 31; \& 32. 
reduce the negative effects caused by such practices in the South African financial markets. ${ }^{143}$ Accordingly, notwithstanding the fact that the JSE was rated as the number one stock exchange by the World Federation of Exchanges with regard to regulation in 2010,144 it is submitted that the existing gaps in the enforcement of the market abuse prohibition in relation to some specific aspects of the South African financial markets could weaken the stability and integrity of the South African financial markets in future. Consequently, it is recommended that the FSB should consider establishing its own mandatory legally binding guidelines on market transparency to prevent relevant trading information asymmetry problems associated with issuers and market abuse activity. ${ }^{145}$ Moreover, the determination of a reasonable degree of certainty in terms of the JSE Listing Requirements should not be only contingent upon the issuers of listed securities and their directors to avoid possible subjectivity which could hamper the JSE's market transparency enforcement efforts. ${ }^{146}$ Additionally, the Financial Markets Act should be amended to enact provisions that specifically enforce market transparency best practices in relation to over the counter commodities and derivatives markets. ${ }^{147}$ The Financial Markets Act should be further amended to accommodate new adequate provisions specifically dealing with investor due diligence to prevent market abuse-related financial risks in the South African financial markets. ${ }^{148}$ Another option could be the enacting of a specific statute that solely deals with market transparency, issuer transparency and investor due diligence to enable the FSB and the JSE to curb systemic risks and possible cross-border market abuse activity in the South African financial markets. ${ }^{149}$ Moreover, the Credit Rating Services Act should be applicable to private credit ratings of securities and financial instruments in both the regulated and unregulated financial markets to discourage market abuse activities in these markets. ${ }^{150}$

It is, therefore, hoped that the recommendations as enumerated in this article will be utilised by the relevant stakeholders in the future to enhance the combating of market abuse activities in South Africa.

\section{References}

\section{Books}

Avgouleas E The Mechanics and Regulation of Market Abuse: A legal and Economic Analysis (Oxford University Press Oxford 2005) Benade ML et al Entrepreneurial Law $3^{\text {rd }}$ ed (Lexis Nexis Butterworths Durban 2003)

Beuthin RC and Luiz SM Beuthin's Basic Company Law 3rd ed (Butterworths Durban 2000)

Lyon GJ \& Du Plessis JJ The Law of Insider Trading in Australia (The Federation Press Sydney 2005)

Milne A et al Henochsberg on the Companies Act 3rd ed (Butterworths Durban 1975)

\section{Journal articles}

Bhana N "Take-Over Announcements and Insider Trading Activity on the Johannesburg Stock Exchange" 1987 South African Journal of Business Management 198-208

Bhattacharya U \& Daouk H "The World Price of Insider Trading" 2002 Journal of Finance 75-108

Botha D "Control of Insider Trading in South Africa: A Comparative Analysis" 1991 SA Merc LJ 1-18

Botha D "Increased Maximum Fine for Insider Trading: A Realistic and Effective Deterrent?" 1990 SALJ 504-508

Cassim R "An Analysis of Market Manipulation under the Securities Services Act 36 of 2004 (Part 1)" 2008 SA Merc LJ 33-60

Fischel DR and Ross DJ "Should the Law Prohibit 'Market Manipulation' in Financial Markets" 1991 Harvard Law Review 503-553

Henning JJ and Du Toit S "The Regulation of False Trading, Market Manipulation and Insider Trading" 2000 Journal for Juridical Science 155-165

Jooste R "A critique of the insider trading provisions of the 2004 Securities Services Act" 2006 SALJ 437-460

Jooste R "Insider Trading: A New Clamp-Down" 1991 BML 248-250

Jooste R "Insider Dealing in South Africa-The Criminal Aspects" 1990 De Ratione 21-28

Kaufmann C \& Weber RH "The Role of Transparency in Financial Regulation" 2010 Journal of International Economic Law 779-797

${ }_{143}$ Cassim "An Analysis of Market Manipulation under the Securities Services Act 36 of 2004 (part 1)" 2008 SA Merc LJ 33 33-36.

${ }^{144}$ National Treasury Reviewing the Regulation of Financial Markets in South Africa: Policy Document Explaining the Financial Markets

Bill 2011 August 20115.

145 See paragraph 2.1.2 above.

146 See paragraph 2.1.2 above.

147 See paragraph 2.1 .2 above.

148 See paragraph 2.2 .2 above.

149 See paragraph 2.2.2 above.

150 See paragraph 2.4.2 above. 
Luiz SM "Prohibition Against Trading on Inside Information-The Saga Continues" 1990 SA Merc LJ 328-332

Luiz SM "Insider Trading Regulation - If at First You Don't Succeed..." 1999 SA Merc LJ 136-151

Osode PC "The new South African Insider Trading Act: Sound law reform or legislative overkill?" 2000 Journal of African Law 239-263

Osode PC "The Regulation of Insider Trading in South Africa: A Public Choice Perspective" 1999 African Journal of International and Comparative Law 688-708

Van der Lingen B "Tougher Legislation to Combat Insider Trading" 1997 FSB Bulletin 10

Van Deventer G "New watchdog for insider trading" 1999 FSB Bulletin 3

Van Zyl FH "Aspekte van Beleggersbeskerming in die Suid-Afrikaanse Reg" 1992 Transactions of the Center for Business Law 231-357

\section{Case law}

Pretorius and Another v Natal South Sea Investment Trust 19653 SA 410 (W)

Legislation

Companies Act 71 of 2008

Consumer Protection Act 68 of 2008

Financial Markets Act 19 of 2012

Financial Advisory and Intermediary Services Act 37 of 2002

Securities Services Act 36 of 2004

Bills

Credit Rating Services Bill B-2011

Financial Markets Bill B-2011

Financial Markets Bill B12-2012

\section{Thesis and dissertations}

Chitimira H A Comparative Analysis of the Enforcement of Market Abuse Provisions (LLD-thesis Nelson Mandela Metropolitan University 2012)

Chitimira H The Regulation of Insider Trading in South Africa: A Roadmap for an Effective, Competitive and Adequate Regulatory Statutory Framework (LLM-dissertation University of Fort Hare 2008)

Swart L The Legal Framework Pertaining to Selected Segments of the Financial Market (LLM Dissertation Nelson Mandela Metropolitan University 2011)

\section{Commissions, Reports and other Relevant Material}

\section{South Africa}

The King Task Group into Insider Trading Legislation Minority Report on Insider Trading 1997

The King Task Group into the Insider Trading Legislation First Report 15 May 1997

The King Task Group into the Insider Trading Legislation Final Report 21 October 1997

Van Wyk de Vries Commission of Inquiry into the Companies Act of 1973

\section{Australia}

D'Aloisio T The New ASIC: Addressing Today's Challenges and Building for the Longer Term, speech to the Australian Corporate Lawyers Association, 7 November 2008

\section{European Union}

Cinquegrana P The Need for Transparency in Commodity and Commodity Derivatives Markets ECMI Research Report 3 December 2008

International Organisation of Securities Commissions IOSCO Urges Greater International Coordination in the Oversight of Credit Rating Agencies IOSCO Media Release 011/2008 17 September 2008 


\section{United States of America}

Schapiro ML Testimony before the Financial Crisis Inquiry Commission Concerning the State of the Financial Crisis 14 January 2010

The US Treasury Financial Regulatory Reform, A New Foundation: Rebuilding Financial Supervision and Regulation Report 17 June 2009

United States Senate Permanent Subcommittee on Investigations Wall Street and the Financial Crisis: Anatomy of a Financial Collapse Majority and Minority Staff Report 13 April 2011

\section{Newspaper reports}

Chanetsa B "Insider Trading is Notoriously Hard to Prosecute" Business Report 26 April 2004

\section{Internet sources}

Anonymous "Reason for Global Recession: In Plain Simple English" <http://www.theindianblogger.com/problems/reasons-for-globalrecession-in-plain-simple-english> (accessed 07-07-2013)

American Securitisation Forum's Project Restart Proposals <http:/www.americansecuritization.com/story.aspx?id=2657> (accessed 0808-2013)

Bake M, Hawken K \& Parker E "The EU Regulation of Credit Rating Agencies Approved" <http://www.mayerbrown.com/publications larticles. asp?id=6529\&nid=6> (accessed 12-06-2011)

Financial Stability Board "Principles for Reducing Reliance on CRA Ratings" <http://www.financialstabilityboard.org/publications Ir_101027.pdf > (accessed 12-06-2011)

Group of Twenty "The Global Plan for Recovery and Reform 2 April 2009" <http://www.g20.org/Documents/final-communique.pdf> (accessed 27-08-2011)

Group of Twenty London Summit Communiqué <http://www.g20.org/Documents/g20_communique_020409.pdf> (accessed 17-062011)

Group of Twenty "Declaration on Strengthening the Financial System-London 2 April 2009" <http://www.g20.org/Documents /Fin Deps Fin Reg_Annex 020409 1615final.pdf> (accessed 27-08-2011)

International Organisation of Securities Commissions Objectives and Principles of Securities Regulation May 2003 $<$ http://www.iosco.org/library/pbdocs/pdf/IOSCOPD154.pdf > (accessed 07-07-2011)

International Organisation of Securities Commissions Objectives and Principles June $2010<$ <ttp://www.iosco.org/library /pbdocs/pdf/IOSCOPD329.pdf> (accessed 07-07-2013)

International Monetary Fund "The Initial Lessons of the Global Financial Crisis" (2009) <http://www.imf.org/external/np/pp/eng 12009/020609.pdf> (accessed 09-07-2011)

International Organisation of Securities Commissions Task Force on Unregulated Financial Markets and Products Technical Committee Unregulated Financial Markets and Products Final Report September 2009 <http://www.iosco.org/library/pbdocs /pdf/IOSCOPD301.pdf> (accessed 07-07-2013)

International Organisation of Securities Commissions Task Force on Unregulated Financial Markets and Products Consultation Report (05-05-2009) <http://www.iosco.org/library/pbdocs/pdf//OSCOPD290.pdf> (accessed 07-07-2011)

International Organisation of Securities Commissions Objectives and Principles May $2003<$ <ttp://www.iosco.org/library/pbdocs/pdf /IOSCOPD154.pdf> (accessed 07-07-2011)

International Organisation of Securities Commissions The Subprime Crisis Final Report May 2008 <http://www.iosco.org /library/pubdocs/pdf/IOSCOPD273.pdf> (accessed 21-08-2011)

International Organisation of Securities Commissions Good Practices in Relation to Investment Managers' Due Diligence When Investing in Structured Finance Instruments July $2009<$ <ttp://www.iosco.org/library/pubdocs/pdf/IOSCOPD300.pdf> (accessed 21-08-2013)

International Organisation of Securities Commissions The Role of Credit Rating Agencies in Structured Finance Market Report March 2008 <http://www.iosco.org/library/pubdocs/pdf//OSCOPD263.pdf> (accessed 14-06-2011)

JSE Listing Requirements <http://www.jse.co.za> (accesssed 13 October 2013)

Le Vine SS \& Malgadi AM "Mortgage Crises, Derivatives and Economic Chaos" (2009) <http://asbbs.org/files/2009/PDF/M /MalgadiA2.pdf> (accessed 17-07-2013)

Myburgh A \& Davis B "The Impact of South Africa's Insider Trading Regime: A Report for the Financial Services Board" (25-03-2004) $<$ http://www.genesis-analytics.com/public/FSBReport.pdf> (accessed 09-02-2013)

Nanto DK The Global Financial Crisis: Analysis and Policy Implications Congressional Research Service Report (02-10-2009) $<$ http://www.crc.gov/congressional/Research/Service/Report.RL34742.pdf> (accessed 12-07-2013)

Paulo S "Europe and the Global Financial Crisis Explained in 10 Sheets: Taking Stock of the EU's Policy Response" April 2011 Fondation Robert Schuman <http://www.robert-schuman.eu/frs-fichecrisefi-qe200-en.pdf> (accessed 04-07-2013)

Secretariat of the European Banking Committee "Financial Turbulence: Following Up the October 2007 Ecofin"<http://ec.europa.eu linternal_market/bank/docs/ebc/ebc170308_en.pdf> (accessed 14-07-2011) 
Van Deventer G "Anti-Market Abuse Legislation in South Africa" (10-06-2008) <http://www.fsb.co.za/public/marketabuse /FSBReport.pdf> (accessed 05-05-2013)

Vander Stichele M "EU Financial Reform: Some Small Steps, but no Fundamental Changes in Sight" (2010) <http://somo.nl/dossiersen/sectors/financial/eu-financial-reforms/newsletters> (accessed 08-07-2013)

Verhelst S "Addressing the Financial Crisis: The EU's Incomplete Regulatory Response" 2010 Egmont Institute for International Relations Paper 39 <http://www.egmontinstitute.be.ep39.pdf> (accessed 08-07-2011) 